\title{
An economic analysis of the production of hydrogen from wind-generated electricity for use in transport applications
}

Paper published in : Energy Policy, vol. 39, n 5, May 2011, pp. 2957-2965

\section{Authors}

P. Menanteau* ${ }^{\mathrm{i}}$, LEPII, Université de Grenoble - CNRS

Corresponding author : philippe.menanteau@upmf-grenoble.fr

LEPII, BP 47, F-38040 Grenoble cedex 9

tel : 33 (0)4 56528574 ; fax : 33 (0)4 56528571

M.M. Quéméréii , EDF R\&D

Département Eco-Efficacité et Procédés Industriels

Site des Renardières - ECUELLES

F-77818 MORET SUR LOING cedex

\author{
A. Le Duigou iii , Coordinator HyFrance3 project, CEA, \\ CEN Saclay \\ F- 91191 Gif Sur Yvette Cedex \\ S. Le Bastard ${ }^{\text {iv }}$, intern at EDF R\&D, \\ c/o Département Eco-Efficacité et Procédés Industriels \\ Site des Renardières - ECUELLES \\ F - 77818 MORET SUR LOING cedex
}

\begin{abstract}
Wind-generated electricity is often considered a particularly promising option for producing hydrogen from renewable energy sources. However, the economic performances of such systems generally remain unclear because of unspecified or favourable assumptions and operating conditions. The aim of this paper is to clarify these conditions by examining how the hydrogen produced is used. The analysis which has been conducted in the framework of the HyFrance 3 project concerns hydrogen for transport applications. Different technical systems are considered such as motorway hydrogen filling stations, Hythane ${ }^{\circledR}$-fueled buses or second-generation biofuels production which present contrasted hydrogen use characteristics. This analysis reveals considerable variations in hydrogen production costs depending on the demand profiles concerned, with the most favourable configurations being those in which storage systems are kept to a minimum.
\end{abstract}

\section{Keywords :}

Hydrogen production, wind power, demand profiles, 


\section{Introduction}

While the prospects for developing hydrogen use in stationary applications should not be ignored, the main focus today is on the use of this energy carrier in mobile applications. Most studies that have looked into the development of hydrogen consider its use in transport applications and in the framework of ambitious climate policies. In this type of context, producing hydrogen from zero-carbon sources would become a prerequisite, albeit not always sufficient on its own, implying important changes in the energy mix used to produce hydrogen beyond 2030: introduction of $\mathrm{CO}_{2}$ capture, the use of nuclear power and the gradual inclusion of higher proportions of renewable energy. Among these renewables, wind energy could play a key role since this is a sector that is growing rapidly and one in which performance is constantly improving. This growth could be further consolidated by the hydrogen sector through the development of storage systems to compensate for the intermittent nature of wind energy.

Detailed analyses of the production of hydrogen from wind energy have been carried out over the last several years. While some of the results appear promising, generally speaking the associated costs are far higher than those entailed in producing hydrogen by methane reforming and to a lesser extend, coal gasification or water electrolysis using the existing electricity mix (IEA, 2005 ; Bartels et alii, 2010 ; Protech-H2, 2009). However, it is not always possible to analyse these published results because the assumptions are insufficiently explicit (HyWays, 2007) with regard to production and operating conditions.

The aim of the present study, which was conducted in the framework of HyFrance3 (Cf Box 1), is to show that while results clearly depend on the technical and economic assumptions that are made, they also depend to a large degree on the hydrogen demand profiles concerned. While the most obvious case is that of meeting hydrogen demand for hydrogen-powered vehicles in motorway filling stations, we shall also examine more specific profiles that also involve the use of hydrogen as a fuel: a fleet of Hythane ${ }^{\circledR}$-fueled buses (methane - hydrogen mixture) and a process for producing second-generation biofuels (BtL 2G). Finally, we also present results for a non-transport configuration involving the storage of wind-generated electricity in the form of hydrogen, the aim being to evaluate the interest in such a system in the context of intermittent electricity supply sources.

\section{The HYFRANCE3 Project}

The aim of the HyFrance3 project is to assess developments in the use of hydrogen in industry and the cost of hydrogen for mobile applications in French regions (Le Duigou et al., 2010).

The project lasting 20 months (May 2009 - Nov 2010) involves a consortium of 10 partners: Air Liquide, Total, EdF R\&D, GDF Suez, CNRS-LEPII, IFP, AFH2, ALPHEA, ADEME (co-funder and partner) and the CEA (coordinator).

Complementing the medium- and long-term vision (2020 - 2050) developed in HyFrance1 and HyFrance2 (J.-M. Agator et al, 2006), which were national applications of the European HyWays project, HyFrance3 was set up to examine prospects and developments as well as the economic competitiveness of of different steps of the hydrogen value chain, for the mid-term 2020-2030, in the context of industrial and energy applications: 
- current situation and changes in demand for hydrogen in industrial markets, - mass storage and distribution in the Rhône-Alpes and PACA regions, - and estimation of the costs of producing hydrogen from wind power for different transport requirements.

\section{Statement of problem}

Producing hydrogen from wind energy is often cited as a method for increasing the proportion of wind power in the energy mix since such production can absorb the fluctuations in the resource and create new uses for the electricity produced, particularly in transport applications. But the technical and economic analyses performed for windhydrogen systems remain partial and should be developed further.

A hydrogen production system based on wind energy can be set up in three different ways:

- Electricity produced from the wind turbine, or the wind turbine array, can be dedicated solely to hydrogen production, without connection to the grid;

- Grid connection can provide back-up electricity for hydrogen production to ensure that the electrolyzer can operate at full capacity even if there is insufficient wind;

- Grid connection can ensure back-up electricity when there is insufficient wind power, as in the previous configuration, but it can also provide the opportunity for injecting surplus electricity production into the grid if the electrolyzer does not have the capacity to use it.

With the addition of hydrogen storage, production can be adapted to the characteristics of hydrogen demand. Grid electricity prices must also be taken into account, since it does not always make sense economically to purchase electricity at peak tariffs in order to continue to produce hydrogen at times when there is insufficient wind power.

These configurations differ therefore in terms of the volume of hydrogen produced for a given wind energy production capacity, the technologies chosen (in particular for the electrolyzer), the hydrogen production costs, and the impact on the electricity grid.

The present study estimates the cost of producing hydrogen from wind energy by simulating different options for producing hydrogen by electrolysis using wind energy, grid electricity and hydrogen storage, taking into account the end-use of the hydrogen.

\section{Literature review}

Over the last few years there has been growing interest in the possibilities offered by hydrogen storage and the direct use of hydrogen (for example to fuel vehicles) as ways of overcoming the problems of large-scale storage of electricity. It is not possible to mention all of the studies published on the subject, but we have reviewed the results of some studies that are closely related to the particular aspects of our own (hydrogen production from wind energy with or without grid connection).

The configurations described in the literature differ widely: a system with electrolyzer to produce hydrogen at the wind farm then transport and store it elsewhere, or a system with electricity transmitted via the grid and production of hydrogen at the point of use, for example. Similarly, the capacity of the electrolyzers and storage facilities varies depending 
on the demand profiles in question. Finally, and most importantly, the assumptions concerning the costs of the different segments of the hydrogen production/storage chain vary considerably and of course have a decisive influence on the hydrogen production costs obtained. For these reasons, rather than comparing the results with our own, we simply review the assumptions made in these studies and the general level of the costs obtained.

Linneman et al. (2007) examined the possibilities and economic interest of utilizing intermittent wind-generated electricity in the form of hydrogen. The authors looked at two contrasting technical solutions: a small (experimental) system to supply 100 vehicles for one year with hydrogen produced by a single 1.5 MW wind turbine; and a large system with a group of $100 \mathrm{MW}$ electrolyzers supplied by a $1000 \mathrm{MW}$ wind farm. The first case is quite similar to the configurations studied in the HyFrance3 project. The second is considerably different in that it requires a transport and distribution infrastructure to supply the filling stations and industrial and domestic consumers. The overall production cost, including the costs of production, transport and distribution $\left(2^{\text {nd }}\right.$ case $)$ and storage, was estimated at $24 € / \mathrm{kg}^{\mathrm{V}}$ for the experimental system, and $10 € / \mathrm{kg}$ for the large-scale configuration. According to the authors, cost reductions can be obtained thanks to the possibility of economies of scale for the different components, especially the electrolyzers, which represent a large part of the required investment.

These results have been confirmed by several studies, including in particular that by Jorgensen et al. (2008). For several wind energy development scenarios, they observed that hydrogen production costs were extremely high when the rate of use of the electrolyzers was low. They concluded that it would be difficult to envisage installing electrolyzers that would operate essentially to utilize surplus wind-generated electricity during periods of excess production, even in situations where there is a high penetration of wind energy. Similarly, Aguado et al. (2009) confirmed that a wind farm with a hydrogen energy storage system avoided the problems of grid management associated with wind-generated electricity production and helped increase grid penetration of intermittent energy sources. But they also found that the benefits of having better control of intermittent electricity generation did not compensate for the additional investment in the hydrogen storage system.

Bartholomy (2005) looked at the possibilities of producing hydrogen from wind sources to fuel vehicles in California. He too studied two options. In the first, electrolyzers produced hydrogen at the wind farm site itself, as and when the wind power was available. But the large underground storage reservoirs required for such an option would make this type of scheme uneconomic at present. In the second, a distributed production model, the windgenerated electricity was transmitted through the grid to electrolyzers installed at the points of use. The costs of each option were estimated assuming huge growth in the hydrogen industry and a positive impact on the grid of greater control of intermittent renewable energy production. However, the extremely favourable results can be explained to a large degree by the assumptions. Thus, the cost of the electrolyzers was estimated at $670 € / \mathrm{kW}$ in the short term and less than $170 €$ in the long term, while the cost of the wind turbines ( $670 € / \mathrm{kW}$ ) no longer corresponds to today's prices. For distributed production the costs obtained for the short term were around $4 € / \mathrm{kg}$, but the wind/grid ratio was not known. For the long term, the cost was estimated at around $2.3 € / \mathrm{kg}$ for centralized production using wind energy alone and including underground storage facilities that would cost very little per kilo of hydrogen $(0.03 € / \mathrm{kg})$. 
With favourable assumptions concerning the cost of electrolyzers and the cost of a $\mathrm{kWh}$ of wind power, Levene et al. (2006) found comparable results. They tested two options. The first involved centralized hydrogen production at the wind turbine site with the hydrogen delivered to end-users, while in the second case the wind power was distributed through the grid and used to produce hydrogen at the point of use. In the first case, the wind turbines produced electricity for the grid during peak hours when prices were high and hydrogen when prices were low. An important characteristic of the model is that it allowed for demand not to be met, so that when there was no wind no hydrogen was produced. However, in the second case, the demand represented by a filling station had to be met, which meant introducing hydrogen storage. As in the previous study, the assumed cost of the electrolyzers was low (530 €/ kW falling to $220 € / \mathrm{kW}$ in the long term) as was that of the wind energy which was taken as $27 € / \mathrm{MWh}$ (compared with around $80 € / \mathrm{MWh}$ in the present study). Estimated costs for centralized production were low since in this configuration there were no hydrogen storage facilities and no delivery costs were included: $4.0 € / \mathrm{kg}$ in the short term decreasing to $1.6 € / \mathrm{kg}$ in the long term. Aggregate wind sources in the case of the decentralized production configuration led to an improvement in the capacity factor of the electrolyzers, which reached $90 \%$ as compared with $80 \%$ in the first case. Consequently the costs were even lower than for the centralized production option despite the addition of a storage system: $2.9 € / \mathrm{kg}$ in the short term, dropping to $1.7 € / \mathrm{kg}$ for the longer term.

Greiner et al. (2007) also estimated costs of this order (3.0 €/ $/ \mathrm{kg})$ for hydrogen produced from wind power with grid connection. Their study examined two configurations for producing hydrogen from wind-generated electricity on a Norwegian island: a small offgrid system with a back-up diesel power generator and a system connected to the Norwegian electricity grid which absorbed surplus production and supplied electricity when no wind at all was available. In this configuration, the electrolyzer was sized so that it operated practically at constant load and storage was reduced as much as possible with the result that, thanks to the low cost of electricity in Norway, the hydrogen production cost was around $3 € / \mathrm{kg}$. For the off-grid system with a $3 \mathrm{MW}$ wind turbine $(950 € / \mathrm{kW})$ linked to a 2 MW capacity electrolyzer, the hydrogen production cost was much higher at around $6.5 € / \mathrm{kg}$.

Generally speaking, hydrogen production costs were found to be much higher for off-grid configurations. Costs for systems with grid connection were found to be relatively low (2 $3 € / \mathrm{kg}$ ), but the assumptions made were (very) favourable with respect to the capacity factors of the electrolyzers and the wind turbine costs.

\section{Scenarios studied and principal results}

The main purpose of the present study was to determine the cost of producing hydrogen from wind-generated electricity in different system configurations. The systems considered and the main results are presented hereafter. 


\subsection{Case studies}

\subsubsection{Technical and economic assumptions}

The most important technical and economic assumptions used in the study are presented in the following table. The wind energy produced was estimated on the basis of real wind power records in the Marseille area in 2005. All prices and costs are expressed in euros (2008 economic conditions).

Table 1: Technical and economic data (* costs and characteristics take into account a built-in AC/DC converter, ** 20 years for operation on 10 -year basis with intermittent operation)

\begin{tabular}{|c|c|c|c|}
\hline $3 \mathrm{MW}$ wind turbine & . & & \\
\hline & Height of rotor & & $100 \mathrm{~m}$ \\
\hline & Lifetime & & 20 yrs \\
\hline & Investment & & $1400 € / \mathrm{kW}$ \\
\hline & O\&M & & $28 € / k W$ \\
\hline \multirow[t]{5}{*}{ Electrolyzer } & & Alkaline* $^{*}$ & PEM \\
\hline & Efficiency & $65 \%$ & $75 \%$ \\
\hline & Lifetime & 20 or 10 yrs ** & $5000 \mathrm{~h}$ \\
\hline & Investment & $1290 € / k W$ & $16,250 € / \mathrm{kW}$ \\
\hline & O\&M & $21 € / \mathrm{kW}$ & $488 € / k W$ \\
\hline \multicolumn{4}{|l|}{$3 \mathrm{MW}$ fuel cell } \\
\hline & Lifetime & & $20 \mathrm{yrs}$ \\
\hline & Investment & & $1500 € / \mathrm{kW}$ \\
\hline & O\&M & & $0.3 € / \mathrm{kW}$ \\
\hline \multicolumn{4}{|l|}{$\mathrm{H}_{2}$ storage } \\
\hline & Capacity per unit & & $350 \mathrm{~kg}$ \\
\hline & Lifetime & & $20 \mathrm{yrs}$ \\
\hline & Investment & & $500 € / \mathrm{kg}$ \\
\hline & O\&M & & $30 € / \mathrm{kg}$ \\
\hline
\end{tabular}

Source: proprietary data from HyFrance's industrial partners

Other important technical assumptions are as follows:

- Wind power: the wind turbines considered had a unit capacity of $3 \mathrm{MW}$ and generated ac current. On the basis of the study assumptions, the annual electricity production of a $3 \mathrm{MW}$ wind turbine was $6.9 \mathrm{GWh}$ and its capacity factor $26.3 \%$.

- Electrolysis: the electrolyzer is the heart of the system that enables hydrogen to be produced from available wind energy. Two electrolysis technologies were considered: alkaline electrolysis (mature technology) and proton exchange membrane (PEM) technology, often considered to be the most appropriate for managing the intermittent nature of renewable energies. Since no real data were available concerning alkaline electrolysis, it was assumed that intermittent operation would reduce the lifetime of the electrolyzer by a factor of 2 compared with an electrolyzer operating continuously

- Hydrogen compression: when it leaves the electrolyzer, the hydrogen is at 30 bars and must be compressed to 200 bars for storage in the $350 \mathrm{~kg}$ capacity tube 
- Fuel cell: the fuel cell was considered only in the system where electricity was stored. In this case a Solid Oxide Fuel Cell (SOFC) was used.

- Electricity prices: different prices were applied for peak and off-peak periods.The purchase price during peak hours (7h00 to $10 \mathrm{~h} 00$ and $18 \mathrm{~h} 00$ to $21 \mathrm{~h} 00$ on weekdays (P WD)) was $9.4 \mathrm{c} € / \mathrm{kWh}$ and during off-peak hours (WE and OP WD) was 3.8 $\mathrm{c} € / \mathrm{kWh}$.

\subsubsection{The systems studied}

Figure 1 : Systems studied

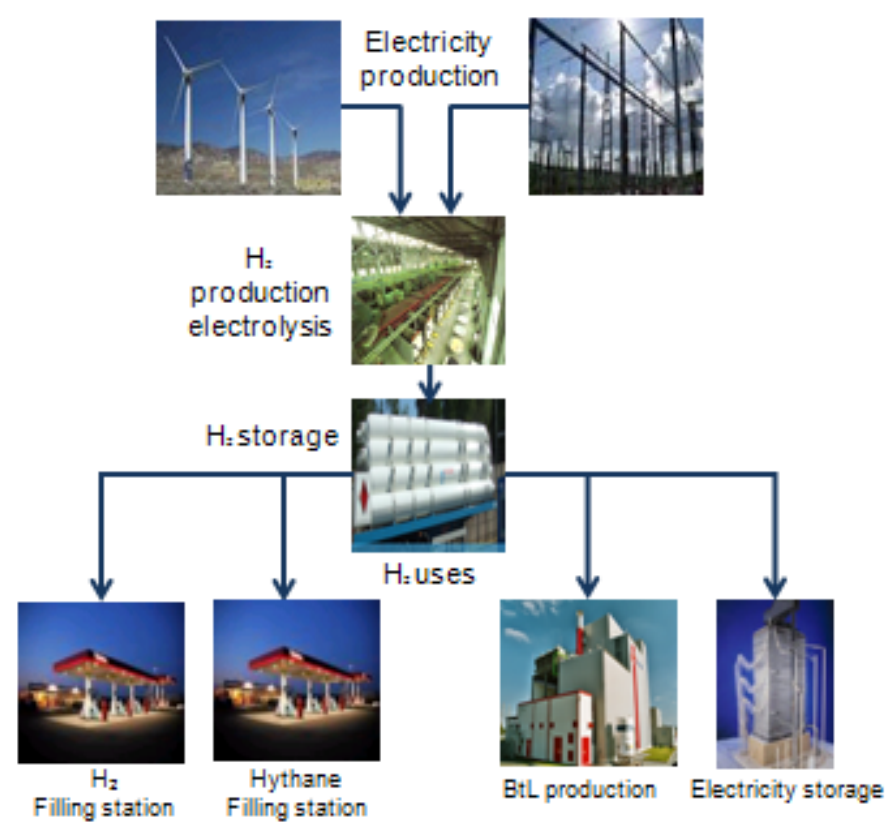

The systems studied are pictured in Figure 1 above and are divided into four different sequences:

1. Production of electricity:

- Wind energy only

- Grid connection to supplement wind-generated electricity for H2 production

- Grid connection to export wind electricity during peak hours (H2 is produced during off-peak hours)

2. Production of hydrogen production

- alkaline electrolysis,

- proton exchange membrane (PEM) electrolysis,

3. Storage of hydrogen in tube trailers (in gaseous form). 


\section{Hydrogen usage \\ - motorway filling station \\ - Hythane ${ }^{\circledR}$ for a fleet of buses \\ - production of second-generation biofuels \\ - method of storing intermittent electricity}

\subsubsection{Hydrogen demand scenarios}

Four different hydrogen usage scenarios have been considered with totally different demand profile in order to estimate their influence on production costs

\section{Filling station}

Hydrogen demand was based on the fuel demand of a typical motorway petrol station. Monthly demand was very irregular with a significant peak in annual demand in July and August, and the highest daily demand between $7 \mathrm{~h}$ and $19 \mathrm{~h}$. Average hourly demand was estimated close to $100 \mathrm{~kg} / \mathrm{h}$ but the peak in july is above $350 \mathrm{~kg} / \mathrm{h}$.

\section{Hythane ${ }^{\circledR}$}

Hythane ${ }^{\circledR}$ is a mixture of natural gas and hydrogen ( $80 / 20 \%$ by volume). Hydrogen improves combustion efficiency and, if the hydrogen is produced by a CO2-neutral process (from wind energy or a low-carbon electricity mix, for example), greenhouse gas emissions are also lower compared with natural gas for equivalent energy performance. The hydrogen demand used in this study was equivalent to the Hythane ${ }^{\circledR}$ fuel needs of a fleet of 100 buses. Hourly consumption of hydrogen was assumed to be constant throughout the year at $12.5 \mathrm{~kg} / \mathrm{hr}$.

\section{$2^{\text {nd }}$ generation biofuel}

In the present study, we tested the idea of partially adjusting the proportions of hydrogen and carbon monoxide in the biomass gasification process so as to optimize the consumption of biomass by adding hydrogen produced elsewhere. The biofuel production capacity of the unit considered was 2000 barrels a day, which would require around 3000 $\mathrm{kg} / \mathrm{hr}$ of hydrogen. It was assumed that the hydrogen and carbon monoxide proportions would be adjusted for the most part by gas shift so that the hydrogen produced by the wind power would be in a minority and could be transferred continuously (as and when it was produced) to the biofuel production process without intermediate storage.

\section{Electricity storage}

In this scenario, a hydrogen fuel cell was used to generate electricity. One of the ideas tested in the study involved producing hydrogen during off-peak hours and re-injecting electricity into the grid during peak hours. This is the only scenario examined in the study that required the use of a fuel cell.

\subsection{The HOMER calculation tool}

The study was performed using the HOMER calculation tool developed by the National Renewable Energy Laboratory (NREL, 2004). This economic optimization model helps to identify the energy production system with the lowest costs for meeting any particular final energy demand, using different assumptions. 
The technical and economic parameters of the technologies concerned are input into the model along with the environmental conditions (wind, etc.), specific obligations (proportion of renewables in the energy mix, etc.), and the economic characteristics of the overall energy project (discount rate, lifecycle of project, etc.). HOMER provides results in the form of total discounted costs for the lifetime of the project. This tool can be used to describe system operation for an entire year and in hourly time steps, making it particularly suited to taking into account the intermittent nature of wind-generated energy.

\subsection{Main results}

The results are presented as discounted costs of hydrogen production for the 4 demand configurations and for off-grid or grid-connected systems.

\section{Filling station}

Table 2 below summarizes the results for the filling station demand scenario

Table 2: Filling station - cost of hydrogen production (*reduced lifetime=lifetime of 10 years)

\begin{tabular}{|c|c|c|c|c|c|c|c|c|c|c|c|c|}
\hline 心 & & 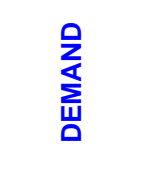 & 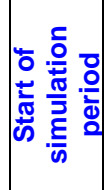 & 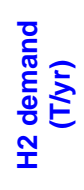 & 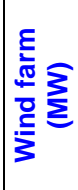 & 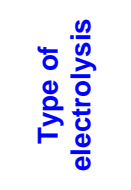 & 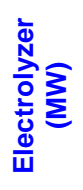 & 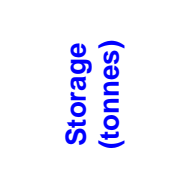 & 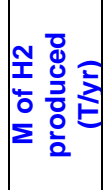 & \multicolumn{2}{|l|}{ 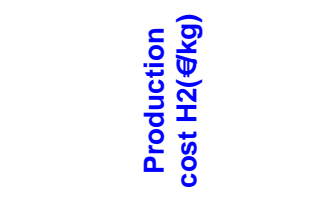 } & 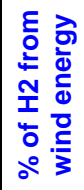 \\
\hline 1 & & Normal & lan & 856 & 24 & $\begin{array}{l}\text { alkaline, } \\
\text { reduced } \\
\text { lifetime* }\end{array}$ & 24 & 143 & 911 & \multicolumn{2}{|c|}{$20 € / \mathrm{kg}$} & $100 \%$ \\
\hline 2 & $\frac{0}{\bar{x}}$ & Normal & Jan. & 856 & 24 & $\begin{array}{l}\text { alkaline, } \\
\text { reduced } \\
\text { lifetime * }\end{array}$ & 24 & $\begin{array}{c}93 \\
\text { (excess elec } \\
\text { dissipated) } \\
\end{array}$ & 862 & \multicolumn{2}{|c|}{$17 € / \mathrm{kg}$} & $100 \%$ \\
\hline 3 & 嵌 & Reduced & 7 & 720 & 21 & $\begin{array}{l}\text { alkaline, } \\
\text { reduced } \\
\text { lifetime* }\end{array}$ & 21 & 129 & 798 & \multicolumn{2}{|c|}{$20 € / \mathrm{kg}$} & $100 \%$ \\
\hline 4 & & peak & Jan. & 720 & 21 & $\begin{array}{l}\text { alkaline } \\
\text { reduced } \\
\text { lifetime * }\end{array}$ & 21 & 51 & 720 & \multicolumn{2}{|c|}{$15 € / \mathrm{kg}$} & $100 \%$ \\
\hline 5 & \multirow{2}{*}{ 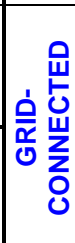 } & Normal & Jan. & 856 & 9 & $\begin{array}{l}\text { alkaline, } \\
\text { reduced } \\
\text { lifetime* }\end{array}$ & 30.1 & 7 & 856 & $\begin{array}{l}\text { Peak/off-peak } \\
\text { prices }\end{array}$ & $11 € / \mathrm{kg}$ & $40 \%$ \\
\hline 6 & & $\begin{array}{l}\text { Reduced } \\
\text { peak }\end{array}$ & Jan. & 720 & 9 & $\begin{array}{l}\text { alkaline, } \\
\text { reduced } \\
\text { lifetime*}^{*}\end{array}$ & 10.3 & 7 & 720 & $\begin{array}{l}\text { Peak/off-peak } \\
\text { prices }\end{array}$ & $7 € / \mathrm{kg}$ & $47 \%$ \\
\hline
\end{tabular}

Case 1 corresponds to a system totally isolated from the grid and where all the electricity produced is used to meet hydrogen demand. This type of configuration requires extensive storage facilities for 143 tonnes of hydrogen (20 years lifetime calculation), but tank was filled to the maximum level only for a very short period (140 tonnes for 3\% of the time, essentially in June). Furthermore, the tank contained more hydrogen at the end of the year than it did in January, indicating that hydrogen was produced in excess. This surplus production is directly linked to the fact that $3 \mathrm{MW}$ "steps" of wind power capacity were used in the model. In such a realistic configuration, the hydrogen production cost was 20 $€ / \mathrm{kg}$; this includes hydrogen overproduction resale (if not, the price increases by only ca. 1 $€ / \mathrm{kg}$ ). In addition, wind power differences will necessarily occur from one year to another, thus leading to unavoidable and unpredictable exess hydrogen (and/or electricity) production situations, from which it seems difficult to take advantage of (oversized or specific storage investments, monitoring, existing market, ....). 
Given the significant weight of storage costs in the economic assessment (roughly 50\% of investment costs and $80 \%$ of operating costs), several options were tested to try and reduce the size of storage facilities. Thus, in case 2, the requirement to use all the electricity generated to produce hydrogen was removed, in order to minimise the hydrogen produced in excess of requirements. In this case, around $5 \%$ of the electricity generated was not used to produce hydrogen, but it had to be dissipated. The optimum storage tank size would be 93 tonnes, which is one third less than in the previous case. In this configuration, the hydrogen production cost was $17 € / \mathrm{kg}$.

As said above, hydrogen demand increases dramatically in July and August. If we assume that this demand can be met with hydrogen produced from another source (methane for instance), the need for hydrogen produced from wind energy can be reduced as well as the storage volume required. In cases 3 and 4, annual demand was thus reduced to 720 tonnes, compared with 856 tonnes in the previous cases. Case 3 is in fact identical to case 1 (i.e. all electricity generated was used to produce hydrogen), and case 4 is identical to case 2 (i.e. only the electricity needed to produce hydrogen was consumed). While the results for cases 1 and 3 are much the same, the case 4 simulation resulted in a substantial reduction in the size of the hydrogen storage system and in the hydrogen production cost, which was 15 $€ / \mathrm{kg}$.

In cases 5 and 6, we simulated systems in which wind energy was supplemented with electricity from the grid in order to produce enough hydrogen to meet demand. Clearly these are theoretical cases, but the aim was to try and reduce the volume of the hydrogen storage system (which was chosen as equivalent to the average consumption for 3 days, much the same as for petrol in a regular filling station). The electrolyzer was sized such that the highest hourly hydrogen demand could be met. By comparing cases 2 and 5, or 4 and 6 , it can be deduced that connection to the electricity grid led to a significant reduction in the cost of hydrogen production. Thus, the cost difference between cases 2 and 5 was 6 $€ / \mathrm{kg}$ (and as much as $9 € / \mathrm{kg}$ between cases 1 and 5), and $7 € / \mathrm{kg}$ between cases 4 and 6 (and as much as $13 € / \mathrm{kg}$ between cases 3 and 6). However it should be stated that for an off-grid installation, all the hydrogen was produced from a renewable source (wind) whereas in the case of a grid-connected system, less than $50 \%$ of the hydrogen was produced from windgenerated electricity.

\section{Hythane ${ }^{\circledR}$}

The following table summarizes the results obtained for the Hythane ${ }^{\circledR}$ demand scenario.

Table 3: Hythane ${ }^{\circledR}$ - Cost of hydrogen production (*reduced lifetime=lifetime of 10 years, **standard= lifetime 20 years)

\begin{tabular}{|c|c|c|c|c|c|c|c|c|}
\hline & 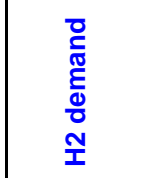 & 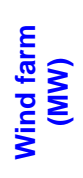 & 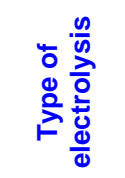 & 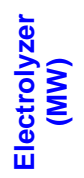 & 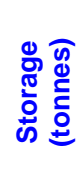 & 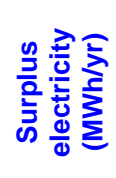 & 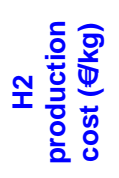 & 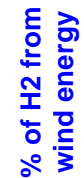 \\
\hline OFF-GRID & \begin{tabular}{|c}
$12.5 \mathrm{~kg} / \mathrm{hr}$ \\
109.5 \\
tonnes/yr \\
-100 \\
buses
\end{tabular} & 3 & $\begin{array}{l}\text { alkaline, } \\
\text { reduced } \\
\text { lifetime* }\end{array}$ & 3 & 15 & 196 & $19 € / \mathrm{kg}$ & $100 \%$ \\
\hline
\end{tabular}




\begin{tabular}{|c|c|c|c|c|c|c|c|c|c|}
\hline $\begin{array}{l}\text { GRID- } \\
\text { CONNECTED }\end{array}$ & $\mid \begin{array}{c}49.4 \mathrm{~kg} / \mathrm{hr} \\
432.7 \\
\text { tonnes/yr } \\
-396 \\
\text { buses }\end{array}$ & 3 & $\begin{array}{l}\text { alkaline, } \\
\text { standard }^{\star \star}\end{array}$ & 3 & 0.050 & 0 & $\begin{array}{c}\text { Peak/off- } \\
\text { peak } \\
\text { prices }\end{array}$ & $4 € / \mathrm{kg}$ & $26 \%$ \\
\hline
\end{tabular}

In this scenario, the production of hydrogen to fuel a fleet of buses running solely on Hythane ${ }^{\circledR}$ was simulated. It was assumed that the fleet operated 24 hours a day and that hydrogen demand was therefore constant. Hydrogen demand for a fleet of 100 buses would be $12.5 \mathrm{~kg} / \mathrm{hr}$.

Two situations were tested:

- The 3 MW wind turbine without grid connection was used to meet hydrogen demand. As in the previous scenario, the requirement to use all the electricity generated to produce hydrogen was removed, which meant that only the amounts of hydrogen needed had to be produced. Surplus electricity represented only 3\% (196 $\mathrm{MWh} / \mathrm{yr}$ ) of total production. The electrolyzer operated intermittently in synchronization with the wind turbine.

- The 3 MW electrolyzer was supplied on an ongoing basis with electricity from the wind turbine (unit capacity $3 \mathrm{MW}$ ) with the grid used for back-up. Hydrogen production was greater than the initial demand, which was taken as $49.4 \mathrm{~kg} / \mathrm{hr}$, corresponding to a fleet of 400 buses. Since hydrogen production was guaranteed thanks to the supplementary power from the grid, storage was reduced to a minimum, namely one hour of production and $50 \mathrm{~kg}$.

In the off-grid case, hydrogen storage (15 t) costs may represent up to $50 \%$ of capital and close to $75 \%$ of operating costs. The hydrogen production costs were reduced considerably by the addition of grid electricity. This saving was obtained by reducing the size of the storage system to a minimum, made possible by matching the times the hydrogen was produced with the times it was consumed, which remained constant throughout the year.

\section{2nd generation biofuel}

The table below summarizes the results obtained for the BtL 2G biofuel demand scenario. Hydrogen storage systems were not required in any of the 6 cases simulated since the hydrogen produced by the systems represented only a small proportion of the hydrogen requirements of the process (between 1 and 7\% depending on the case) and could be integrated directly into the process (which absorbed any fluctuations).

Table 4: Second generation biofuel - cost of hydrogen production (*reduced lifetime=lifetime of 10 years, ${ }^{* *}$ standard= lifetime of 20 years)

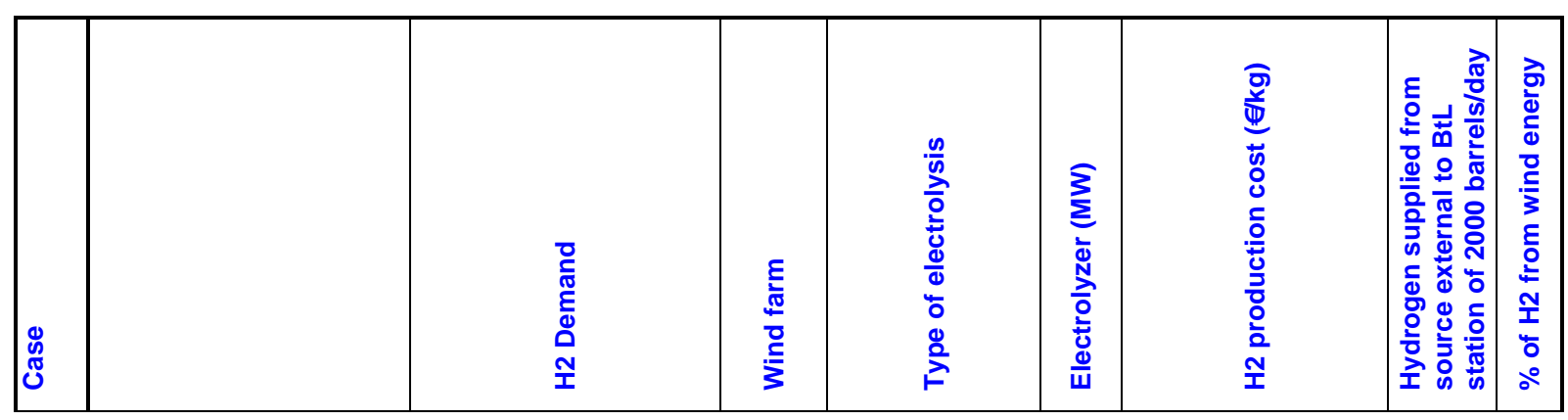




\begin{tabular}{|c|c|c|c|c|c|c|c|c|c|}
\hline 1 & \multirow{3}{*}{ OFF-GRID } & $\begin{array}{l}\text { As produced by } \\
\text { available wind energy, } \\
456 \text { Tlyear }\end{array}$ & \multirow{2}{*}{$12 \mathrm{MW}$} & $\begin{array}{l}\text { alkaline, reduced } \\
\text { lifetime* }\end{array}$ & 12 & \multicolumn{2}{|l|}{$9 € / \mathrm{kg}$} & $2 \%$ & $\begin{array}{l}100 \\
\%\end{array}$ \\
\hline 2 & & $\begin{array}{l}\text { As produced by } \\
\text { available wind energy, } \\
526 \mathrm{~T} / \text { year }\end{array}$ & & PEM & 12 & \multicolumn{2}{|l|}{$400 € / \mathrm{kg}$} & $2 \%$ & $\begin{array}{l}100 \\
\%\end{array}$ \\
\hline 3 & & $\begin{array}{l}\text { As produced by } \\
\text { available wind energy, } \\
1823 \mathrm{~T} / \text { year }\end{array}$ & $48 \mathrm{MW}$ & $\begin{array}{l}\text { alkaline, reduced } \\
\text { lifetime* }\end{array}$ & 48 & \multicolumn{2}{|l|}{$9 € / \mathrm{kg}$} & $7 \%$ & $\begin{array}{l}100 \\
\%\end{array}$ \\
\hline 4 & $\begin{array}{l}\text { GRID-CONNECTED } \\
\text { (PURCHASE) }\end{array}$ & $198 \mathrm{~kg} / \mathrm{h}, 1732 \mathrm{~T} /$ year & $12 \mathrm{MW}$ & $\begin{array}{l}\text { Standard } \\
\text { alkaline** }\end{array}$ & 12 & $\begin{array}{l}\text { Peak/off- } \\
\text { peak prices }\end{array}$ & $4 € / \mathrm{kg}$ & $7 \%$ & $26 \%$ \\
\hline 5 & $\begin{array}{l}\text { GRID-CONNECTED } \\
\text { (PURCHASEISALE) }\end{array}$ & $52.1 \mathrm{~kg} / \mathrm{h}, 456$ T/year & $12 \mathrm{MW}$ & $\begin{array}{l}\text { alkaline } \\
\text { standard }^{\star *}\end{array}$ & 3,2 & $\begin{array}{l}\text { Peak/off- } \\
\text { peak prices }\end{array}$ & $5 € / \mathrm{kg}$ & $2 \%$ & $45 \%$ \\
\hline 6 & $\begin{array}{l}\text { GRID-CONNECTED } \\
\text { (SALE DURING PEAK } \\
\text { HOURS) }\end{array}$ & $\begin{array}{l}\text { As produced by } \\
\text { available wind energy } \\
\text { during off-peak, nil } \\
\text { during peak hours, } 177 \\
\text { T/year }\end{array}$ & $12 \mathrm{MW}$ & $\begin{array}{l}\text { alkaline, reduced } \\
\text { lifetime* }\end{array}$ & 12 & $\begin{array}{l}\text { Peak/off- } \\
\text { peak prices }\end{array}$ & $12 € / \mathrm{kg}$ & $<1 \%$ & $\begin{array}{l}100 \\
\%\end{array}$ \\
\hline
\end{tabular}

In the first three cases, the wind turbine was isolated from the grid and the hydrogen was produced as and when the wind energy was available, with a production cost of $9 € / \mathrm{kg}$ for systems using alkaline electrolysis. Cases 1 and 3 (Table 5 above) differ only in the size of the system studied (12 and $48 \mathrm{MW}$ wind farms, which correspond to capacities frequently found today). Insofar as in both cases all the hydrogen produced was used in the 2G biofuel production process, it was to be expected that the hydrogen production cost would be the same, the only difference between the two systems being in the \% of hydrogen injected into the system (2 and 7\%). In case 2, alkaline electrolysis was replaced by PEM electrolysis, using present-day performance for this technology. The cost of producing hydrogen in this case was totally unacceptable, but this should not be used to draw any conclusions about the technology. It is important to note that PEM electrolysis is a technology currently under development and therefore performance is likely to improve in the future. The result merely indicates that further progress must be made before it will be financially viable to use PEM electrolysis in this type of project.

In cases 4, 5 and 6, the systems were connected to the grid, but for different reasons in each case:

- When there was insufficient wind power, grid electricity was used to enable basic operation of the electrolyzer (case 4).

- The electrolyzer was sized such that same annual production (456t/yr) could be obtained as that in case 1, but with a basic production profile of $52.1 \mathrm{~kg} / \mathrm{hr}$. The $12 \mathrm{MW}$ electrolyzer in case 1 was replaced by a 3.2 MW electrolyzer. When the wind power exceeded the requirements of the electrolyzer, the surplus electricity was sold. Conversely, when there was insufficient wind power to run the electrolyzer, the additional electricity required was purchased from the grid (case 5).

- The wind-generated electricity was sold on the grid during peak hours and hydrogen was produced only during off-peak hours (case 6).

The hydrogen production costs obtained here were between 4 and $12 € / \mathrm{kg}$.

\section{Electricity storage}

The following table summarizes the results obtained for the electricity storage scenario. 
Table 5: Electricity storage $(*$ NPV=Net Present Value=Total discounted profits-Total discounted costs, ${ }^{* *}$ reduced lifetime=lifetime of 10 years)

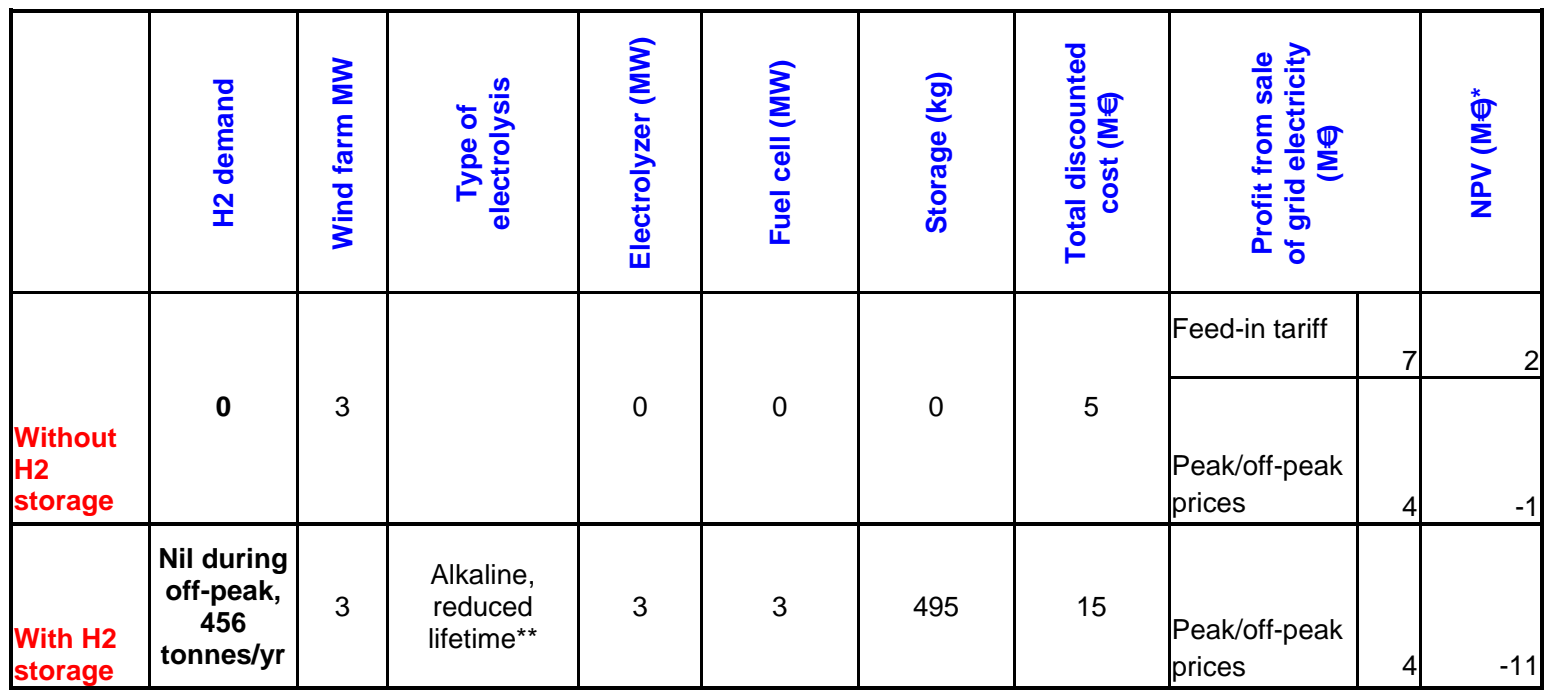

In this part, three configurations were compared:

- $\quad$ wind energy was sold through the grid at a guaranteed feed-in tariff ( $82 € / \mathrm{MWh}$ ) without hydrogen production,

- wind power was sold through the grid in accordance with peak/off-peak rates without hydrogen production,

- wind energy produced during off-peak hours was stored in the form of hydrogen and converted back to electricity on the grid via a fuel cell during peak hours; wind energy produced during peak hours was also sold through the grid.

With this latter operating mode, the production of intermittent wind-generated energy was transformed into a peak demand electricity production system. The results are not shown as hydrogen production costs, which were very high in all cases. Calculation of the Net Present Value (NPV) shows that with the assumptions made the only scenario with a positive NPV was the one in which all the wind energy produced was sold at the feed-in tariff.

\section{Analysis}

In the case of the filling station supplied by an off-grid wind turbine, without the possibility of grid back-up, the high storage costs led to a hydrogen production cost of between 15 and $20 € / \mathrm{kg}$. This cost is naturally much higher than in the case of a gridconnected installation (between 8 and $11 € / \mathrm{kg}$ ), which does not have the same requirements in terms of hydrogen storage. Nevertheless, it can be seen that in the case of an off-grid installation, hydrogen was produced solely from renewable electricity (wind) whereas when the installation was connected to the grid less than $50 \%$ of the hydrogen was produced from wind energy. According to Linemann et al. (2007), who obtained similar results for a filling station connected to the grid $(12 € / \mathrm{kg})$, costs of this order would lead to usage costs three times higher than those of a diesel vehicle, a comparison that does not take into account the cost of purchasing a vehicle (fuel cell or diesel powered) nor environmental externalities.

The demand profile used for the filling station corresponds to real demand observed in a motorway filling station, where there is a strong annual peak during the holiday period in July and August. To limit this peak effect, another demand profile, incorporating a 
"reduced peak", was also studied. In this case, demand was capped at the maximum level for an average day (resulting in a 14\% reduction compared with the "normal" profile). With grid connection, production costs were reduced considerably by reducing the peaks in demand. Since the electrolyzer was sized for peak demand, its utilization rate in fact increased markedly and costs decreased when the demand peaks were reduced. In the case of an isolated installation, reducing the peaks in demand also led to cost reductions (15 $€ / \mathrm{kg}$ ) except in the case where the model did not allow for surplus wind energy production, in which case the oversized storage system absorbed the savings made by reducing the peaks (20€/kg).

For an off-grid installation, the cost of producing hydrogen for a fleet of buses running on Hythane ${ }^{\circledR}$ was not significantly different from the cost obtained for a filling station, despite the fact that the demand profile was less variable. On the other hand, where the station was connected to the grid, the production cost $(4 € / \mathrm{kg})$ was comparable to the more favourable cases reported in the literature. However, as in the simulation by Greiner et al.,(2007) only part (26\%) of the hydrogen was produced from renewable sources.

The demand profile for a $2 \mathrm{G}$ biofuel filling station was the most favourable for intermittent wind-energy production since it was assumed that hydrogen was produced only when wind energy was available, without the need for hydrogen storage facilities. This configuration yielded the lowest production cost in the case of hydrogen produced exclusively from wind-generated electricity, namely $9 € / \mathrm{kg}$. In the grid-connected configurations, the production cost was halved ( $4 € / \mathrm{kg}$ ) thanks to the lower cost of grid electricity and the possibility of using the grid to stabilize the operation of the electrolyzer at full capacity. However, as indicated above, using grid electricity to supplement wind energy only guaranteed that $26 \%$ of hydrogen was produced from renewable energy sources. In both configurations, the wind farm is dimensioned so that the gas shift process is not disrupted and the hydrogen supplied from external source to the BtL station never exceeds $7 \%$ of the 2000 barrels produced a day by the BtL 2G biofuel plant. This may be regarded as a modest impact to the biofuel production, but it helps improving the mass efficiency of biomass transformation and as such contributes to the preservation of energy sources.

Figure 2: Effect of demand type on the cost of producing hydrogen from wind power 

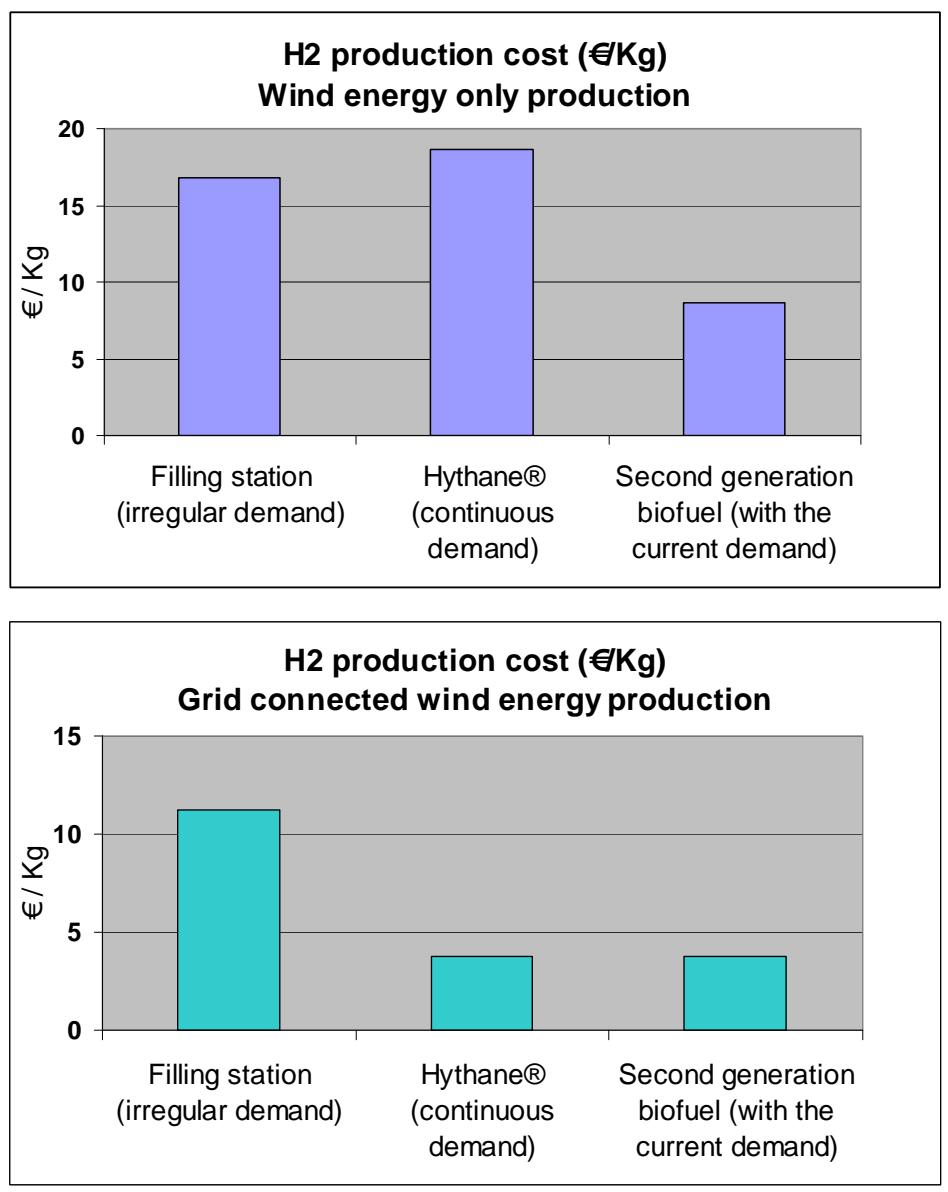

Our final scenario did not simulate hydrogen production as such, but rather a method of storing wind-generated electricity temporarily so that it could be reinjected into the grid at times when it would be more profitable financially. The results obtained confirm that in present economic conditions, absolute levels and variability in market prices for electricity are not sufficient to balance the production plus storage costs of wind energy. However, with the introduction of a feed-in tariff mechanism and no storage it was possible to obtain a positive NPV.

We looked at the economic interest of hydrogen storage in the case of wind energy being purchased according to market prices and not at a guaranteed price. A simplified representation distinguishing peak and off-peak prices was tested to determine whether it might be economically viable to store electricity during off-peak periods and then sell it at a higher price during peak hours. None of the configurations tested resulted in a positive NPV. The difference in price between off-peak and peak tariffs was not sufficient to compensate for efficiency losses (production of $\mathrm{H}_{2}$ and fuel cell). Even without losses, the difference was too small to make up for the very high investment costs needed to create $\mathrm{H}_{2}$ storage systems.

Finally, an important result of this work is that one cannot consider a unique cost of hydrogen production from wind energy, or even two costs depending on wether the system is isolated or not from the grid. Given the high costs of hydrogen storage, it is necessary to consider complete supply chains including specific demand profiles of hydrogen uses and appropriate storage capacities. With small to medium wind farms, decentralised electrolysis, grid and offgrid situations and the profile demand of a filling station, we have obtained hydrogen costs for uses in transport (from 11 to $17 € / \mathrm{kg}$ for filling station) that are higher than the costs 
mentioned for hydrogen from wind energy (near $5 € / \mathrm{kg}$ - cf supra - or even below as for instance in Hyways (2007) : 2 to $3.5 € / \mathrm{kg}$.

Our objective was to explore the possibility to develop hydrogen applications in transport uses in the short to medium term. For this reason we have studied several configurations based on decentralised hydrogen production in order to avoid the complex decision process, time delay and huge investments and operating costs of an hydrogen transport infrastructure. Of course, the existence of a transport infrastructure would change the perspectives for the development of hydrogen production from renewable sources. Similarly, innovation and cost decrease of small hydrogen storage options will improve the competitiveness of decentralised hydrogen solutions for transport uses; but for the time being, this option that requires $1 \mathrm{~kg}$ of H2 / 100 $\mathrm{km}$ is much more costly than conventional (fossil fuel) solutions.

The costs of hydrogen from wind energy are much lower when hydrogen is used to improve efficiency of BtL transformation or incorporated in Hythane for transport application. In the most favourable case, when the connection to the electric grid is possible, basic operation of the electrolyzer and removal of hydrogen storage allow the costs to be comparable to those obtained with usual electrolysis and SMR production: ca. $3.5 € / \mathrm{kg}$ for electrolysis when considering an electricity price of $66 € / \mathrm{MWH}$ (Roads2HyCom, 2009), and between ca. 1.6 and $3 € / \mathrm{kg}$ for central and on-site SMR (IEA, 2005 ; HyWays, 2007 ; Roads2HyCom 2009)..

This may have important consequences for the development of hydrogen from wind energy in transport applications. If the objective is not to maximise the quantity of renewable hydrogen used in transport applications but to facilitate the integration of intermittent sources of electricity, hydrogen for BtL transformation or Hythane production has also to be considered. As a way to transform wind energy in biofuel this option allows a greater contribution of intermittent energy sources in the energy mix. Of course, the quantities of hydrogen in transport uses will at the end not be the same but, the positive effect on the integration of intermittent renewable sources in the energy mix may also be strategic to reach environmental objectives.

\section{Conclusion}

Overall, the study has shown that the cost of producing hydrogen from wind-generated electricity varied widely depending on the configurations tested. While results quite naturally differed according to the assumptions made concerning the cost and performance of the system components (wind turbines, electrolyzers, hydrogen storage system, etc.), we also showed that costs could differ significantly depending on the demand profiles concerned.

Thus, the most favourable costs were found for BtL 2G systems and Hythane ${ }^{\circledR}$ in which hydrogen was produced continuously by connecting the system to the grid, depending on the availability of the wind, without the need for an intermediate storage between production and usage: $4 € / \mathrm{kg}$, the contribution of wind energy to the production of $\mathrm{H}_{2}$ then accounting for $26 \%$. On the other hand, in the classic case of supplying a filling station, the variability of demand was another factor to add to the variability of the resource, making it necessary to include expensive hydrogen storage facilities in the system and then leading to costs up to ca. $20 € / \mathrm{kg}$ (ca. 7 to $11 € / \mathrm{kg}$ when connected to the grid, $50 \% \mathrm{H}_{2}$ from wind energy). The wind only hydrogen production cost ("hydrogen when available") is about $9 € / \mathrm{kg}$. 
Although this question has not been examined in the present study, it is clear that technological progress in hydrogen storage will be a key variable. Given the impact of storage volume on the cost of hydrogen production, future reductions in storage costs with the development of large geological storage facilities at wind farms or smaller storage systems near filling stations could lead to a significant drop in the cost of the hydrogen to the end-user.

Grid connection, which also helps reduce storage costs by supplementing intermittent wind energy, has a considerable impact on hydrogen production costs. With continuity of supply, storage requirements are reduced (although they cannot be entirely dispensed with where demand is irregular) and the rate of use of electrolyzers can be maximized. In a configuration of this kind, production costs are relatively low (4€/kg), comparable to usual SMR or gridconnected electrolysis production costs, but the hydrogen is not $100 \%$ renewable (26\% to $50 \%$ from wind energy). And most importantly, this remains a textbook case, since at present there are no supply contracts enabling hydrogen producers to purchase low-priced electricity as and when necessary to make up for shortages of wind-generated energy. This was not included in our study, but an interesting complementary study would be to evaluate if (or not) the electric transmission system could find a benefit if this kind of contracts was developed. The question to know if it is easier to sell "intermittent electricity" than to buy it still remains open.

Last, with the assumptions used in the study, storing electricity in the form of hydrogen is not an economically worthwhile method of compensating for intermittent power generation. The cost of producing the hydrogen and storing it and then converting it back to electricity is still far too high to justify an investment of this order: NPV always negative when considering peak/off-peak prices.. Besides, there are other technical solutions currently available or under development to facilitate the insertion of intermittent energy into the mix (pumped storage plants, use of fleets of electric vehicles to store energy, remote control of demand, etc.). In current economic conditions, storing wind-generated electricity in the form of hydrogen is not of major interest. On the other hand, in certain conditions, wind-generated electricity could be a promising option for producing hydrogen for use as a fuel in the more general sense $(\mathrm{H} 2$, as well as BtL containing $\mathrm{H} 2$, and Hythane $\left.{ }^{\circledR}\right)$.

\section{Acknowledgements}

This study was performed in the framework of Hyfrance3, a project to examine the development of hydrogen demand in industry and estimate the cost of distribution in regions. The authors thank ADEME for co-funding the project, as well as all the partners (Air Liquide, Total, EdF R\&D, GDF Suez, CNRS-LEPII, IFP, AFH2, ALPHEA, ADEME, CEA).

\section{References}

Agator J.-M. et al., 2006, “Towards a French Hydrogen Energy Roadmap: the HyFrance Project”, World Hydrogen Energy Congress; WHEC 2006; June $13^{\text {th }}$ to $16^{\text {th }}$, Lyon (France).

Aguado M., Ayerbe E., Azcarate C., 2009, “Economical assessment of a wind-hydrogen energy system using WindHyGen® software”, International Journal of Hydrogen Energy, vol 34 (2009) 2845 2854.

Bartels, J.R., Pate M.B., Olson N.K., 2010, “An economic survey of hydrogen production from conventional and alternative energy sources”,International Journal of Hydrogen Energy, vol 35. 
Bartholomy O., 2005, “Renewable hydrogen from wind in California”, Proceedings, National Hydrogen Association, March 2005.

European Commission (EC), 2006, World Energy Technology Outlook 2050: WETO-H2,

Greiner C.J., Korpås M., Holen A. T., 2007, “A Norwegian case study on the production of hydrogen from wind power”; International Journal of Hydrogen Energy 32 (2007) 1500 - 1507.

Hyways, 2007, The European Hydrogen Energy Roadmap, HyWays project final report.

International Energy Agency (IEA), 2005, Prospects for hydrogen and fuel cells, Energy Technology Analysis Report.

Jørgensen C., Ropenus S., 2008, "Production price of hydrogen from grid connected electrolysis in a power market with high wind penetration”, International Journal of H2 Energy, vol 33( 2008).

Le Duigou A. et al., 2010, “Aims and First Assessments of the French Hydrogen Pathways Project HyFrance3”; World Hydrogen Energy Congress; WHEC 2010; May $16^{\text {th }}$ to $20^{\text {th }}$, Essen (Germany).

Levene J., Kroposki B., and Sverdrup G., 2006, Wind Energy and Production of Hydrogen and Electricity Opportunities for Renewable Hydrogen, 18 pp.; NREL Report No. CP-560-39534.

Linnemann J. and Steinberger-Wilckens R., 2007, "Realistic costs of wind-hydrogen vehicle fuel production", International Journal of Hydrogen Energy 32 (2007) 1492 - 1499.

National Renewable Energy Laboratory (NREL), 2004, HOMER: The Micropower Optimization Model, NREL/FS-710-35406, March 2004.

Protech-H2, 2009, Synthèse du projet Protech-H2, Enerdata, Rapport de projet à l’ANR.

Roads2HyCom Project / Analysis of the Current Hydrogen Cost Structure - 22 January 2009 (http://www.roads2hy.com/)

\footnotetext{
i Philippe Menanteau, LEPII, Université de Grenoble - CNRS corresponding author : philippe.menanteau@upmf-grenoble.fr tel : $33(0) 456528574$

LEPII

BP 47

F-38040 Grenoble cedex 9

ii Marie-Marguerite Quéméré, EDF R\&D.

iii Alain Le Duigou, CEA, Coordinator HyFrance3 project.

iv Sandra Le Bastard, intern at EDF (April - September 2008)

${ }^{v}$ All costs have been converted to Euros (2008 economic conditions) to facilitate comparison.
} 